\title{
Effect of Adding Macro and Micro Minerals in Pig Feces Fed Diets with Different Levels of Probiotic
}

\author{
Rizal Alcides Robles Huaynate*, Maria Cristina Thomaz, Rodolfo Nascimento Kronka, \\ Alessandro Luís Fraga, Antônio João Scandolera and Fábio Enrique Lemos Budiño \\ Faculdade de Ciências Agrárias e Veterinárias; Universidade Estadual Paulista; Rod. Paulo Donato Castellane, \\ s/n; rizal3@hotmail.com; 14884-900; Jaboticabal - SP - Brasil
}

\begin{abstract}
This study aimed to verify the effect of diets with different doses (0, 100, 200 and 300 ppm) of probiotic on daily fecal production (DFP) and level of macro and micro minerals in feces of nursing ( $1^{\text {st }}$ and $2^{\text {nd }}$ initial phases) and growing pigs and during total period. The DFP, as percentage of body weight, was different $(P<0.05)$ among treatments only at $1^{\text {st }}$ initial phase. Fecal levels of macro and micro minerals were similar $(P>0.05)$ among treatments, with exception of calcium and sodium excretion at $1^{\text {st }}$ initial phase and calcium, zinc and nickel during total period. The addition of a poliprobiotic to diets do not affect fecal production of nursing and growing pigs. However, the presence of microorganisms, added (levels of 200 and 300 ppm) in diets for nursing and growing pigs reduced fecal excretion of calcium, zinc and nickel.
\end{abstract}

Key words: Calcium, digestion, lactobacillus, piglet, zinc

\section{INTRODUCTION}

Pig industry is considered one of the most important economical activities within feed production chain. In this sense, Brazil has the fourth largest world-wide herd and is the fourth largest pork exporter (Roppa, 2003). But, pig performance is prejudiced because of the pathogen dissemination caused by increase of animal density in confinement system.

Beside this, feces accumulation in pig production increases the risk of environment contamination and compromises sustainability of this activity. It is estimated that from the total diet ingredient consumed by pigs, around 45 to $60 \%$ of nitrogen, 50 to $80 \%$ of calcium and phosphorous and 70 to $90 \%$ of potassium, sodium, magnesium, cupper, zinc, manganese and iron are excreted through feces and urine (Kornegay and Harper, 1997). The presence of these minerals in feces increases the problem of environmental pollution.

The level of some minerals, as nitrogen and phosphorous in pig feces is very important because of the risk of soil and water contamination (Rebollar and Mateos, 1999). In many countries, institutions have established the areas for animal feces utilization as fertilizer, which has limited the number of sows on a pig farm (Hacker and Du, 1993). Consequently, the size of the production unit is dependent of the available area for fertilizing with effluents of pig production.

According to Food and Drugs Administration (FDA) of United States, probiotics are a source of viable microorganisms which occurs naturally and might be used directly in total ration for animals (DFM: Direct-Fed Microbial), being classified as

* Author for correspondence 
GRAS (Generally Regarding As Safe) substances. Bertechini and Hossain (1993) referred the preference for the generic term "direct-fed microbial products", which includes other components, as Bacillus sp. and some yeast (noncommon gastrointestinal organisms), enzymes and sub-products of fermentation industry.

The utilization of micro ingredients as probiotics, prebiotics, organic acids and chelating minerals, was reviewed by Menten (2002) where the metabolic effect of micro ingredients was emphasized for reducing pollution effects and improving pig performance. In this sense, pools of health living bacterias and yeasts (poliprobiotics) have been incorporated in diets for improving digestibility and nutrient utilization, especially minerals.

The aim of this work was to evaluate different levels $(0,100,200$ and $300 \mathrm{ppm})$ of probiotic inclusion in diets for nursing $\left(1^{\text {st }}\right.$ initial $+2^{\text {nd }}$ initial periods) and growing pigs in relation to amount of feces production and fecal content of macro and micro minerals.

\section{MATERIAL AND METHODS}

Forty crossbreed (Duroc x Landrace - Large White) barrow piglets were weaned at 22 day-old and $6.17 \pm 0.68 \mathrm{~kg}$ body weight. Animals were housed in $2.55 \mathrm{~m}^{2}(1.55 \times 1.70 \mathrm{~m})$ individual pens with concrete floor, separated by iron bars and wood partition walls for avoiding animal contact. Drinkers were kind communicating vessels and feeders were semi-automatic. The tested product was the poliprobiotic Bacsol-vt ${ }^{\circledR}$, composed mainly by the following bacteria and yeast species: Bacillus subtilis, Bacillus natto, Bacillus megaterium, Lactobacillus acidophilus, Lactobacillus plantarum, Lactobacillus brevis, Lactobacillus casei, Streptococcus lactis, Streptococcus faecalis, Streptococcus termophilus and Saccharomyces cereviseae

Evaluations were done during these following phases:

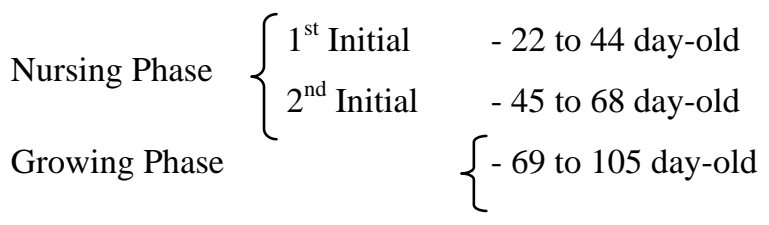

\section{Treatments and experimental diets}

Treatments were:

$\mathrm{T}_{0} \quad$ - Basal Diet (control);

$\mathrm{T}_{100}$ - Basal Diet +100 ppm of probiotic;

$\mathrm{T}_{200}$ - Basal Diet +200 ppm of probiotic;

$\mathrm{T}_{300}$ - Basal Diet +300 ppm of probiotic.

Experimental diets (Table 1) were formulated according to animal requirements of NRC (1998). Diet composition was calculated based on Rostagno et al. (2000). Iso-protein and isoenergetic basal diets (control) with different levels of probiotic were formulated for each phase. The mineral and vitamin supplement was included to the diets according the industry recommendation.

\section{Fecal quantification and macro and micro minerals levels}

Pen floor was cleaned and scraped daily. Twice a week, animal feces produced during $24 \mathrm{~h}$ were individual collected and weighed. After collecting, feces of each animal were homogenized and sampled (15\% of total), stored in plastic bag and frozen for further analysis. During the $1^{\text {st }}$ and $2^{\text {nd }}$ initial and growing phases three, eight and ten feces collections were made, respectively, totaling 240 samples for pig. However, some animals from the treatment without probiotic and the treatment supplemented with $100 \mathrm{ppm}$ of probiotic had diarrhea at $1^{\text {st }}$ initial phase so, their feces were collected only after their recovering.

Feces samples of each pig during each phase were defrosted, homogenized and one sub-sample (200 g) was taken and dried in air oven at $60^{\circ} \mathrm{C}$ for $72 \mathrm{~h}$. Dried sub-samples were ground in knife and ball grinder. Dry matter content of feces (DMF) was determined and the daily fecal production as percentage of pig body weight, on dry matter basis, was calculated.

The sub-samples were homogenized and $0.5 \mathrm{~g}$ of each one of the total of 120 sub-samples were digested in nitroperchloric solution. After digestion, contents of calcium, potassium, magnesium, sodium, cupper, iron, manganese, zinc and nickel were determined by atomic absorption spectrophotometer according to Bataglia (1983). 
Table 1 - Percentual composition and nutritional levels of experimental diets.

\begin{tabular}{|c|c|c|c|}
\hline \multirow{2}{*}{ Ingredients } & \multicolumn{3}{|c|}{ Phases } \\
\hline & $1^{\text {st }}$ Initial & $2^{\text {nd }}$ Initial & Growing \\
\hline Corn & 66.21 & 67.53 & 77.64 \\
\hline Soybean meal & 17.57 & 21.26 & 19.34 \\
\hline Defatted dried milk & 5.16 & 6.00 & - \\
\hline Isolated soybean protein & 5.00 & - & - \\
\hline Soybean oil & - & - & 0.93 \\
\hline Dicalcium phosphate & 1.35 & 1.07 & 0.72 \\
\hline Limestone & 0.77 & 0.68 & 0.86 \\
\hline Sugar cane & 3.00 & 2.74 & - \\
\hline Sodium Chloride (common salt) & 0.33 & 0.25 & 0.15 \\
\hline Mineral and vitamin supplement* & 0.10 & 0.10 & 0.10 \\
\hline L-Lysine $\mathrm{HCl}(78.4 \%)$ & 0.37 & 0.32 & 0.25 \\
\hline DL-Methionine $(99.0 \%)$ & 0.09 & 0.04 & - \\
\hline L-Threonine $(98.0 \%)$ & 0.05 & 0.01 & - \\
\hline Antioxidant & - & - & 0.01 \\
\hline Total $(\mathrm{kg})$ & 100.00 & 100.00 & 100.00 \\
\hline \multicolumn{4}{|l|}{ Calculated Values** } \\
\hline Metabolizable Energy (kcal.kg ${ }^{-1}$ ) & 3,265 & 3,265 & 3,265 \\
\hline Crude Protein $(\%)$ & 19.93 & 17.23 & 15.74 \\
\hline Lysine $(\%)$ & 1.35 & 1.15 & 0.95 \\
\hline Methionine + Cysteine (\%) & 0.74 & 0.63 & 0.55 \\
\hline Threonine $(\%)$ & 0.81 & 0,69 & 0.60 \\
\hline Triptophan $(\%)$ & 0.24 & 0.21 & 0.18 \\
\hline Calcium $(\%)$ & 0.80 & 0.70 & 0.60 \\
\hline Available phosphorous (\%) & 0.40 & 0.32 & 0.23 \\
\hline Sodium $(\%)$ & 0.20 & 0.15 & 0.10 \\
\hline
\end{tabular}

Phosphorous values were estimated by colorimetric method and nitrogen content by Kjeldahl method (Silva, 1998). Daily mineral excretion was calculated by multiplying fecal mineral content by daily fecal production (dry matter). The mineral excretion per kilogram of feed intake was calculated using the formula:

where:

$$
\mathrm{ME} / \mathrm{FI}(\mathrm{g} \text { or } \mathrm{mg})=\mathrm{DME} / \mathrm{DFI}
$$

ME/FI: mineral excretion ( $\mathrm{g}$ or $\mathrm{mg}$ ) per kilogram of feed intake.

DME: daily mineral excretion (g or $\mathrm{mg}$ ).

DFI: daily feed intake $(\mathrm{kg})$.

At the start and at the end of each phase, pigs and the production of feces over $24 \mathrm{~h}$ were weighted and the daily fecal production was calculated as percentage of the pig body weight (DFP/BW). These calculations were done with the objective of to adjust the fecal production to the body weight and the mineral excretion to the feed intake in order to reduce the variation (Crocker and Robson, 2002).

\section{Experimental design}

For controlling differences among initial body weights, a completely randomized block design with four treatments and ten replicates was used and each animal was considered as experimental unit. Variance analysis was performed using GLM proceedings of SAS (Sas ${ }^{\circledR}$ Institute, 1998) and means were compared by Tukey test with $5 \%$ of significance level. The mathematical model used was the following:

Where:

$$
Y i j=u+T i+B j+e i j
$$

Yij - observed value

u - general mean 
$\mathrm{Ti} \quad$ - effect of the levels of probiotic inclusion $\mathrm{i}(\mathrm{i}=1$, ..., 4)

$\mathrm{Bj} \quad$ - block effect $\mathrm{j}(\mathrm{j}=1, \ldots, 10)$

eij - experimental error

\section{RESULTS AND DISCUSSION}

\section{Fecal production}

Table 2 presents the daily feces production estimated in percentage of body weight (DFP/BW) and the dry matter content of feces (DMF) at first and second initial phases, growing phase and total period. At $1^{\text {st }}$ initial phase, the production of feces in relation to the pig body weight was statistically different $(\mathrm{P}<0.05)$ between animals treated with $100 \mathrm{ppm}$ of probiotic and those of control group, probably because these had smaller feed intake than the others. The mean value of this variable in control treatment, at $1^{\text {st }}$ and $2^{\text {nd }}$ initial phases, was
$3.1 \%$, similar to those of $2.5 \%$ found in piglets from five to $25 \mathrm{~kg}$ of body weight by Oliveira et al. (1993). Who observed that in animals from 25 to $100 \mathrm{~kg}$ of body weight (3.68\%) was higher than that of $2.01 \%$ found in animals growing phase. Crocker and Robison (2002) observed values around $0.6 \%$ of daily fecal production in relation to body weight. These differences might be related to the methods used for collecting feces, period of the year, utilization of micro ingredients and that pigs from these studies showed differences in feed intake and conversion.

Table 3 presents daily feces production in wet matter, dry matter content of feces and daily feces production in dry matter, at $1^{\text {st }}$ and $2^{\text {nd }}$ initial phases and growing phase. There were statistical differences $(\mathrm{P}<0.05)$ among animals at different phases. Heavier animals had higher $(\mathrm{P}<0.05)$ fecal production in wet matter.

Table 2 - Means and mean standard errors for daily fecal production in percentage of body weight (DFP/BW) and dry matter content of feces (DMF) of pigs fed diets with different levels of probiotic at nursing phase $\left(1^{\text {st }}\right.$ Initial + $2^{\text {nd }}$ initial) and growing phase and total period.

\begin{tabular}{lcccc}
\hline Phases & \multicolumn{2}{c}{ Treatments } & $\mathbf{T}_{\mathbf{2 0 0}}$ & $\mathbf{T}_{\mathbf{3 0 0}}$ \\
\hline $\mathbf{1}_{\mathbf{0}}^{\text {st }}$ initial & & $\mathbf{T}_{\mathbf{1 0 0}}$ & & \\
DFP/BW (\%) & $3.32 \pm 0.30^{\mathrm{a}}$ & $2.14 \pm 0.09^{\mathrm{b}}$ & $2.74 \pm 0.23^{\mathrm{ab}}$ & $2.54 \pm 0.19^{\mathrm{ab}}$ \\
DMF (\%) & $28.35 \pm 0.58$ & $30.01 \pm 0.97$ & $30.41 \pm 0.54$ & $29.46 \pm 0.89$ \\
$\mathbf{2}^{\text {nd }}$ initial & & & & \\
DFP/BW (\%) & $2.89 \pm 0.23$ & $2.36 \pm 0.17$ & $2.49 \pm 0.16$ & $2.41 \pm 0.15$ \\
DMF (\%) & $30.42 \pm 0.58$ & $30.82 \pm 0.50$ & $31.75 \pm 0.39$ & $31.18 \pm 0.43$ \\
Growing & & & & \\
DFP/BW (\%) & $2.01 \pm 0.21$ & $2.22 \pm 0.21$ & $2.23 \pm 0.10$ & $1.93 \pm 0.16$ \\
DMF (\%) & $31.15 \pm 0.60$ & $29.82 \pm 0.41$ & $31.51 \pm 0.34$ & $31.58 \pm 0.39$ \\
Total period & & & & \\
DFP/BW (\%) & $2.74 \pm 0.16$ & $2.24 \pm 0.12$ & $2.49 \pm 0.09$ & $2.29 \pm 0.10$ \\
DMF (\%) & $29.97 \pm 0.48$ & $30.21 \pm 0.36$ & $31.22 \pm 0.34$ & $30.74 \pm 0.35$ \\
\hline
\end{tabular}

a,b Means followed by the same letter within row are similar by Tukey test $(\mathrm{P}>0.05)$.

Table 3 - Means and mean standard errors for daily fecal production (DFP) in wet and dry matter and dry matter content of feces of pigs at nursing phase $\left(1^{\text {st }}\right.$ Initial $+2^{\text {nd }}$ initial $)$ and growing phase.

\begin{tabular}{|c|c|c|c|}
\hline Phases & $\begin{array}{c}\text { DFP wet matter } \\
(\mathrm{g})\end{array}$ & $\begin{array}{l}\text { Dry matter content } \\
(\%)\end{array}$ & $\begin{array}{c}\text { DFP dry matter } \\
\text { (g) }\end{array}$ \\
\hline $1^{\text {st }}$ initial & $200 \pm 32.24^{\mathrm{c}}$ & $29.6 \pm 8.05^{b}$ & $59 \pm 34.40^{c}$ \\
\hline $2^{\text {nd }}$ initial & $373 \pm 29.57^{b}$ & $31.0 \pm 4.76^{\mathrm{a}}$ & $116 \pm 29.37^{b}$ \\
\hline Growing & $757 \pm 26.10^{\mathrm{a}}$ & $31.2 \pm 4.57^{\mathrm{a}}$ & $236 \pm 24.05^{\mathrm{a}}$ \\
\hline
\end{tabular}

a,b Means followed by the same letter within column are similar by Tukey test $(\mathrm{P}>0.05)$. 
Table 4 - Means and mean standard errors for macro mineral ( $\mathrm{g}$ or $\mathrm{mg}$ ) excreted in feces per kilogram of feed intake (as fed) of pigs fed diets with different levels of probiotic at nursing $\left(1^{\text {st }}\right.$ initial $+2^{\text {nd }}$ initial) and growing phases and total period.

\begin{tabular}{|c|c|c|c|c|}
\hline \multirow[b]{2}{*}{ Phases } & \multicolumn{4}{|c|}{ Treatment } \\
\hline & $\mathbf{T}_{0}$ & $\mathbf{T}_{100}$ & $\mathbf{T}_{200}$ & $\mathbf{T}_{\mathbf{3 0 0}}$ \\
\hline \multicolumn{5}{|l|}{$1^{\text {st }}$ initial } \\
\hline $\mathrm{Ca}(\mathrm{g})$ & $6.19 \pm 0.29^{\mathrm{a}}$ & $4.84 \pm 0.37^{b}$ & $5.29 \pm 0.24^{\mathrm{ab}}$ & $4.39 \pm 0.47^{b}$ \\
\hline$P(g)$ & $5.23 \pm 0.42$ & $4.24 \pm 0.35$ & $4.76 \pm 0.30$ & $4.08 \pm 0.31$ \\
\hline $\operatorname{Mg}(g)$ & $2.32 \pm 0.16$ & $2.00 \pm 0.18$ & $2.17 \pm 0.08$ & $2.02 \pm 0.19$ \\
\hline $\mathrm{K}(\mathrm{g})$ & $4.73 \pm 0.32$ & $3.70 \pm 0.22$ & $3.93 \pm 0.27$ & $3.67 \pm 0.37$ \\
\hline $\mathrm{Na}(\mathrm{mg})$ & $441.00 \pm 167.3^{\mathrm{ab}}$ & $340.00 \pm 37.23^{b}$ & $649.00 \pm 82.61^{\mathrm{a}}$ & $633.00 \pm 112.07^{\mathrm{a}}$ \\
\hline $\mathrm{N}(\mathrm{g})$ & $6.57 \pm 0.45$ & $5.13 \pm 0.28$ & $6.16 \pm 0.43$ & $5.61 \pm 0.46$ \\
\hline \multicolumn{5}{|c|}{$2^{\text {nd }}$ initial } \\
\hline $\mathrm{Ca}(\mathrm{g})$ & $1.96 \pm 0.11$ & $2.10 \pm 0.18$ & $1.95 \pm 0.14$ & $1.87 \pm 0.08$ \\
\hline$P(g)$ & $1.93 \pm 0.10$ & $1.98 \pm 0.13$ & $1.91 \pm 0.08$ & $1.90 \pm 0.07$ \\
\hline $\operatorname{Mg}(g)$ & $0.97 \pm 0.07$ & $1.03 \pm 0.07$ & $0.94 \pm 0.05$ & $0.97 \pm 0.04$ \\
\hline $\mathrm{K}(\mathrm{g})$ & $2.27 \pm 0.15$ & $2.22 \pm 0.14$ & $2.14 \pm 0.10$ & $2.38 \pm 0.11$ \\
\hline $\mathrm{Na}(\mathrm{mg})$ & $282.0 \pm 25.48$ & $272.0 \pm 25.50$ & $244.0 \pm 13.47$ & $274.0 \pm 28.34$ \\
\hline $\mathrm{N}(\mathrm{g})$ & $2.80 \pm 0.20$ & $2.55 \pm 0.17$ & $2.62 \pm 0.12$ & $2.49 \pm 0.12$ \\
\hline \multicolumn{5}{|l|}{ Growing } \\
\hline $\mathrm{Ca}(\mathrm{g})$ & $3.14 \pm 0.29$ & $3.47 \pm 0.28$ & $2.99 \pm 0.22$ & $2.82 \pm 0.20$ \\
\hline$P(g)$ & $2.60 \pm 0.23$ & $2.95 \pm 0.22$ & $2.55 \pm 0.16$ & $2.51 \pm 0.18$ \\
\hline $\operatorname{Mg}(g)$ & $1.60 \pm 0.15$ & $1.77 \pm 0.17$ & $1.48 \pm 0.14$ & $1.56 \pm 0.19$ \\
\hline $\mathrm{K}(\mathrm{g})$ & $3.53 \pm 0.36$ & $3.89 \pm 0.30$ & $3.39 \pm 0.23$ & $3.13 \pm 0.25$ \\
\hline $\mathrm{Na}(\mathrm{mg})$ & $284.0 \pm 27.68$ & $320.0 \pm 35.04$ & $297.0 \pm 25.41$ & $255.0 \pm 21.00$ \\
\hline $\mathrm{N}(\mathrm{g})$ & $3.24 \pm 0.34$ & $3.60 \pm 0.27$ & $3.38 \pm 0.11$ & $2.95 \pm 0.17$ \\
\hline \multicolumn{5}{|c|}{ Total period } \\
\hline $\mathrm{Ca}(\mathrm{g})$ & $3.76 \pm 0.18^{\mathrm{a}}$ & $3.47 \pm 0.23^{\mathrm{ab}}$ & $3.41 \pm 0.14^{\mathrm{ab}}$ & $3.03 \pm 0.20^{\mathrm{b}}$ \\
\hline$P(g)$ & $3.26 \pm 0.17$ & $3.06 \pm 0.19$ & $3.07 \pm 0.11$ & $2.83 \pm 0.14$ \\
\hline $\operatorname{Mg}(g)$ & $1.63 \pm 0.10$ & $1.60 \pm 0.11$ & $1.53 \pm 0.06$ & $1.52 \pm 0.11$ \\
\hline $\mathrm{K}(\mathrm{g})$ & $3.51 \pm 0.22$ & $3.27 \pm 0.19$ & $3.15 \pm 0.16$ & $2.93 \pm 0.19$ \\
\hline $\mathrm{Na}(\mathrm{mg})$ & $336.0 \pm 46.07$ & $313.0 \pm 14.76$ & $393.0 \pm 29.61$ & $381.0 \pm 35.72$ \\
\hline $\mathrm{N}(\mathrm{g})$ & $4.20 \pm 0.21$ & $3.76 \pm 0.20$ & $4.06 \pm 0.13$ & $3.68 \pm 0.16$ \\
\hline
\end{tabular}

a,b Means followed by the same minuscule letter within row are similar by Tukey test $(\mathrm{P}>0.05)$.

Percentage of fecal dry matter at $1^{\text {st }}$ initial phase was smaller $(\mathrm{P}<0.05)$ when compared to $2^{\text {nd }}$ initial phase and growing phase. This fact might be related to higher water content in feces of animals when the digestive system was in development (after the weaning) and this situation could result in high incidence of gastrointestinal disorders.

However, at $2^{\text {nd }}$ initial phase and growing phase the digestive system was completely developed and the incidence of gastrointestinal disorders reduced, consequently, feces had lower water content.

\section{Fecal content of macro and micro minerals}

Table 4 presents fecal macro mineral content per kilogram of feed intake. Fecal macro mineral contents were similar $(\mathrm{P}>0.05)$ among treatments during $1^{\text {st }}$ and $2^{\text {nd }}$ initial phases, growing phase and total period, with exception of calcium at $1^{\text {st }}$ initial phase and total period and sodium at $1^{\text {st }}$ initial phase. At $1^{\text {st }}$ initial phase, animals fed diets with 100 and $300 \mathrm{ppm}$ of probiotic excreted lower $(\mathrm{P}<0.05)$ amounts of $\mathrm{Ca}$ in relation to control group. Pigs fed $100 \mathrm{ppm}$ of probiotic had the lowest feed intake during the $1^{\text {st }}$ initial phase and this reflected in better retention of mineral, as occurred numerically with all of them. However, the feed intake of pigs fed 300 ppm was similar with others and the reduction in Ca excretion could be related to a better microbial equilibrium in pig intestine.

With exception of sodium, all of other minerals (including micro minerals - Table 5) were numerically excreted in lower amounts by pigs fed $300 \mathrm{ppm}$ of probiotic.

In relation to $\mathrm{Na}$, animals fed diets with $100 \mathrm{ppm}$ of probiotic at $1^{\text {st }}$ initial phase eliminated less 
$(\mathrm{P}<0.05)$ amounts than those treated with 200 and $300 \mathrm{ppm}$.

This result might be directly related to higher diarrhea incidence in the group of animals treated with $100 \mathrm{ppm}$ of probiotic since $\mathrm{Na}$ is one of electrolytes responsible by maintenance of osmotic pressure and water cellular level. Thus, $\mathrm{Na}$ excretion is higher than others in gastrointestinal disorders (Mc Dowell, 1992).

Table 5 - Means and means standard errors for micro minerals $(\mathrm{mg})$ excreted in feces per kilogram of feed intake (as fed) of pigs fed diets with different levels of probiotic at nursing phase $\left(1^{\text {st }}\right.$ Initial $+2^{\text {nd }}$ initial $)$, growing phase and total period.

\begin{tabular}{|c|c|c|c|c|}
\hline \multirow[b]{2}{*}{ Phases } & \multicolumn{4}{|c|}{ Treatment } \\
\hline & $\mathbf{T}_{0}$ & $\mathbf{T}_{100}$ & $\mathbf{T}_{200}$ & $\mathbf{T}_{300}$ \\
\hline \multicolumn{5}{|c|}{$1^{\text {st }}$ Initial } \\
\hline $\mathrm{Zn}$ & $280.00 \pm 21.00$ & $270.00 \pm 19.08$ & $245.00 \pm 12.22$ & $225.00 \pm 19.86$ \\
\hline $\mathrm{Mg}$ & $63.99 \pm 6.20$ & $52.93 \pm 5.39$ & $61.25 \pm 4.91$ & $52.83 \pm 4.13$ \\
\hline $\mathrm{Cu}$ & $29.00 \pm 3.15$ & $23.63 \pm 1.80$ & $29.04 \pm 2.33$ & $24.18 \pm 1.89$ \\
\hline $\mathrm{Fe}$ & $805,00 \pm 35,00$ & $615,00 \pm 29,07$ & $795,00 \pm 31,95$ & $658,00 \pm 28,16$ \\
\hline $\mathrm{Ni}$ & $1.92 \pm 0.15$ & $1.88 \pm 0.12$ & $1.67 \pm 0.67$ & $1.47 \pm 0.44$ \\
\hline \multicolumn{5}{|c|}{$2^{\text {nd }}$ Initial } \\
\hline $\mathrm{Zn}$ & $116.0 \pm 6.93$ & $117.0 \pm 7.27$ & $113.0 \pm 4.92$ & $113.0 \pm 4.42$ \\
\hline $\mathrm{Mg}$ & $26.55 \pm 2.02$ & $30.38 \pm 2.58$ & $28.60 \pm 2.28$ & $28.13 \pm 1.54$ \\
\hline $\mathrm{Cu}$ & $13.46 \pm 0.87$ & $13.24 \pm 0.82$ & $13.09 \pm 0.55$ & $13.11 \pm 0.55$ \\
\hline $\mathrm{Fe}$ & $323.00 \pm 22.12$ & $338.00 \pm 25.54$ & $322.00 \pm 18.70$ & $309.00 \pm 12.12$ \\
\hline $\mathrm{Ni}$ & $0.86 \pm 0.08$ & $0.94 \pm 0.08$ & $0.84 \pm 0.07$ & $0.81 \pm 0.06$ \\
\hline \multicolumn{5}{|c|}{ Growing } \\
\hline $\mathrm{Zn}$ & $166.00 \pm 13.00$ & $185.00 \pm 13.24$ & $163.00 \pm 10.40$ & $160.00 \pm 11.56$ \\
\hline $\mathrm{Mg}$ & $38.28 \pm 3.57$ & $42.49 \pm 3.66$ & $34.72 \pm 2.81$ & $36.21 \pm 3.77$ \\
\hline $\mathrm{Cu}$ & $16.16 \pm 1.61$ & $17.44 \pm 1.47$ & $14.70 \pm 1.00$ & $14.47 \pm 0.96$ \\
\hline $\mathrm{Fe}$ & $280.00 \pm 20.90$ & $312.00 \pm 27.94$ & $285.00 \pm 24.25$ & $281.00 \pm 33.51$ \\
\hline $\mathrm{Ni}$ & $0.97 \pm 0.08$ & $1.09 \pm 0.11$ & $0.84 \pm 0.07$ & $0.92 \pm 0.09$ \\
\hline \multicolumn{5}{|c|}{ Total period } \\
\hline $\mathrm{Zn}$ & $254.00 \pm 32.70^{a}$ & $194.00 \pm 14.74^{\mathrm{ab}}$ & $174.00 \pm 6.53^{\mathrm{b}}$ & $166.00 \pm 9.32^{b}$ \\
\hline $\mathrm{Mg}$ & $42.94 \pm 3.20$ & $41.93 \pm 2.74$ & $41.56 \pm 2.06$ & $39.06 \pm 2.38$ \\
\hline $\mathrm{Cu}$ & $19.54 \pm 1.23$ & $18.11 \pm 1.05$ & $18.94 \pm 0.76$ & $17.25 \pm 0.86$ \\
\hline $\mathrm{Fe}$ & $470.00 \pm 25.09$ & $422.00 \pm 27.66$ & $467.00 \pm 25.43$ & $406.00 \pm 28.50$ \\
\hline $\mathrm{Ni}$ & $1.25 \pm 0.07^{\mathrm{ab}}$ & $1.30 \pm 0.07^{\mathrm{a}}$ & $1.12 \pm 0.08^{\mathrm{ab}}$ & $1.07 \pm 0.15^{\mathrm{b}}$ \\
\hline
\end{tabular}

a,b Means followed by the same letter within row are similar by Tukey test $(\mathrm{P}>0.05)$.

Considering that during $1^{\text {st }}$ initial phase, feces were collected only after diarrhea interruption, animals from control group and from treatment with 100 ppm of probiotic lost a lot of $\mathrm{Na}$ during diarrhea and when this intestinal disorder stopped, they excreted less $\mathrm{Na}$ in order to increase absorption and to replace the plasma level of this ion. Fabian et al. (2004) showed that after a period of low availability of an element (nitrogen), pigs improved its retention.

In the total period, animals treated with $300 \mathrm{ppm}$ of probiotic eliminated less $(\mathrm{P}<0.05)$ amounts of $\mathrm{Ca}$ in feces than animals from control group. Considering $2^{\text {nd }}$ initial phase, growing phase and total period, there was a gradual reduction in $\mathrm{Ca}$ excretion with increase of probiotic inclusion in diets, probably because probiotic reduced substantially intestinal $\mathrm{pH}$ and improved $\mathrm{Ca}$ absorption (Jonsson and Conway, 1992). The highest level of probiotic inclusion caused smaller nitrogen excretion (Table 3) during the total period (22 to 105 day-old). Scheuermann (1993) using a probiotic of Lactobacillus $\left(0,10^{8}, 10^{9}, 10^{10}\right.$ UFC. $\mathrm{kg}^{-1}$ ) in diets for growing pig, observed higher nitrogen retention with the highest level of probiotic inclusion. Table 5 presents fecal micro mineral excretion per kilogram of feed intake measured in animals from all treatments.

At $1^{\text {st }}$ and $2^{\text {nd }}$ initial phases and growing phase, there were no differences $(\mathrm{P}>0.05)$ among treatments in relation to all micro mineral excretion. Considering the total period, animals 
treated with 200 and $300 \mathrm{ppm}$ of probiotic excreted less $(\mathrm{P}<0.05)$ amounts of zinc than those of control group; while animals treated with $300 \mathrm{ppm}$ excreted less $(\mathrm{P}<0.05)$ amounts of nickel in relation to those of control group. The lowest $\mathrm{Zn}$ excretion by animals treated with 200 and $300 \mathrm{ppm}$ might be related to the action of microorganisms present in probiotic, which used $\mathrm{Zn}$ in their physiological functions (Mc Dowell, 1992).

When levels of macro and micro minerals in feces of growing pigs fed diet without probiotic determined in this trial $(\mathrm{Ca}=2.01 \%, \mathrm{P}=2.6 \%, \mathrm{Zn}=$ $1095 \mathrm{ppm}, \mathrm{Cu}=104 \mathrm{ppm}$ and $\mathrm{Fe}=1845 \mathrm{ppm}$ ) were compared to results found by Lima et al. (1993) using the same fecal collection method in animals at finishing phase $(\mathrm{Ca}=3.39 \%, \mathrm{P}=2.67 \%, \mathrm{Zn}=$ $830 \mathrm{ppm}, \mathrm{Cu}=124 \mathrm{ppm}$ and $\mathrm{Fe}=6010 \mathrm{ppm}$ and to values observed by Shaw et al. (2002) for the control diet of their study envolving finishing pigs $(\mathrm{Ca}=2.68 \%, \mathrm{P}=1.94 \%, \mathrm{Zn}=801 \mathrm{ppm}, \mathrm{Cu}=98$ ppm and $\mathrm{Fe}=1829 \mathrm{ppm}$ ), it was observed that all minerals, with exception of the $\mathrm{Zn}$, were in lower concentrations in the present and in the Shaw et al. (2002) studies than in Lima et al. (1993) study. The genetic potential of animals must be considered in order to explain the differences (Crocker and Robison, 2002), but the composition of the diets and the level of trace mineral inclusion influences the mineral composition of feces too, as showed by Shaw et al. (2002).

\section{CONCLUSIONS}

The addition of a poliprobiotic to diets did not affect fecal production of nursing and growing pigs. However, the presence of microorganisms, added in know levels to diets, reduced the excretion of minerals.

\section{RESUMO}

O objetivo deste trabalho foi avaliar dietas contendo diferentes doses $(0,100,200$ e 300 ppm) de probiótico sobre a produção diária de fezes (PDF) e teor de macro e microminerais nas fezes de suínos, nas fases de creche e de crescimento e no período total. A PDF, como porcentagem do peso vivo, somente apresentou diferença estatística $(\mathrm{P}<0,05)$ na fase inicial 1 . Os teores de macro e microminerais excretados nas fezes não apresentaram diferença $(\mathrm{P}>0,05)$ entre tratamentos, a exceção de cálcio e sódio na fase inicial $1 \mathrm{e}$ cálcio, zinco e níquel no período total. A adição de um poliprobiótico às dietas, não afetou a produção de fezes dos suínos nas fases de creche e de crescimento. Entretanto, a presença de microrganismos, adicionados (níveis de 200 e 300 ppm) às dietas reduziu a excreção fecal de cálcio, zinco e níquel.

\section{ACKNOWLEDGEMENTS}

This work was supported by Agropecuária Nunes. The authors would like to thank Dr. P. Bellingieri for helpful comments.

\section{REFERENCES}

Bataglia, O. G. (1983), Métodos de análises químicos de plantas. Campinas: Instituto Agronômico. 48 pp.

Bertechini, A. G. and Hossain, S. M. (1993), O fantástico mundo dos probióticos. Campinas: Biotecnal. 97 pp.

Crocker, A. W. and Robison, O. W. (2002), Genetic and nutritional effects on swine excreta. J. Anim. Sci., 80, 2809-2816.

Fabian, J.; Chiba, L. I.; Frobish, L. T.; McElhenney, W. H.; Kuhlers, D. L. and Nadarajah, K. (2004), Compensatory growth and nitrogen balance in grower-finisher pigs. J. Anim. Sci., 82, 2579-2587.

Hacker, R. R. and Du, Z. (1993), Livestock pollution and politics. In: Verstegen, W. A. (Ed.). Nitrogen flow in pig production and environmental consequences. Wageningen: Pudoc Scientific. pp. 3-21.

Jonsson, E. and Conway, P. (1992), Probiotics for pigs. In: Fuller, R. (Ed.). Probiotics. London: The scientific Basis. pp. 259-316.

Kornegay, E. T. and Harper, A. F. (1997), Environmental nutrition: Nutrient management strategies to reduce nutrient excretion of swine. Proff. Anim. Sci., 13, 99-111.

Lima, G. J. M. M.; Oliveira, P. A. V. and Gomes, P. C. (1993), Determinação da digestibilidade aparente e do valor energético do esterco de suíno. In: Congresso Brasileiro de Veterinários Especialistas em Suínos, 6., Concórdia. Anais... Concórdia.

McDowell, L. R. (1992), Minerals in animal and human. California: Science University of Florida, Academy Press. 524 pp.

Menten, J. F. M. (2002), Probióticos, prebióticos e aditivos fitogênicos na nutrição de aves. In: Simpósio Sobre Ingredientes na Alimentação Animal, 2., Campinas. Anais... Campinas: CBNA. pp. 251-276. 
National Research Council. (1998), Nutrient requirements of swine. 10. ed. Washington: National Academy Press. 198 pp.

Oliveira, P. A. V.; Martins R. R.; Pedroso, D.; Lima, G. J. M. M.; Lindner, E. A.; Belli Filho, P.; Castillo Jr., A. B.; Silveira, V. R.; Baldisera, I.; Mattos A. C.; Gossmann, H.; Cristmann, A.; Bonett, E. and Hess, A. Manual de manejo e utilização dos dejetos de suínos. Concordia: Embrapa-CNPSA. pp. 188.

Rebollar, P. G. and Mateos, G. G. (2003), El fósforo en nutrición animal, necesidades, valoración de materias primas y mejora de la disponibilidad. In: Curso de Especialización Avances en Nutrición y Alimentación Animal, 15., Madrid. Anales... Available in: www.etsia.upm.es/fedna/capitulos/99CAP2.pdf. Access on: 15 jan. 2003.

Roppa, L. (2003), Suinocultura no mundo. Porkworld, 3, 14-37.
Rostagno, H. S.; Silva, D. J.; Costa, P. M. A.; Fonseca, J. B.; Soarez, P. R.; Pereira, J. A. A. and Silva, M. A. (2000), Tabelas brasileiras para aves e suínos, composição de alimentos e exigências nutricionais de aves e suínos. Viçosa: UFV. 141 pp.

Scheuermann, S. E. (1993), Effect of de probiotic Paciflor (CIP 5832) on energy and protein metabolism in growing pigs. Anim. Feed Sci. Technol., 41, 181-189.

Shaw, D. T.; Rozemboom, D. W.; Hill, G. M.; Booren, A. M. and Link, J. E. (2002), Impact of vitamin and mineral supplement withdraw and wheat middling inclusion on finishing pig growth performance, fecal mineral concentration, carcass characteristics, and the nutrient content and oxidative stability of pork. $J$. Anim. Sci., 80, 2920-2930.

Silva, D. J. (1998), Análise de alimentos, métodos químicos e biológicos. Viçosa: UFV. 165 pp.

Statistical Analysis System Institute (1998), SAS users guide. Statistics. SAS. Cary. 